\title{
Adaptation of Religion and Local Wisdom in Global Environmental Issues in Indonesia
}

\section{Syafwan Rozi ${ }^{1, *}$, Zulfan Taufik ${ }^{2}$}

1 Institut Agama Islam Negeri (IAIN) Bukittinggi, Indonesia; sya_ra_de@yahoo.co.id

2 Institut Agama Islam Negeri (IAIN) Bukittinggi, Indonesia; zulfantaufik@gmail.com

* Correspondence

Received: 2020-06-21; Accepted: 2020-07-25; Published: 2020-08-29

\begin{abstract}
This study focuses on how the adaptation efforts and survival strategies of local communities in Indonesia to the non-natural pressure on nature and the value of their local wisdom in protecting and preserving the environment. Anthropological, ecological, and related literature on local communities are used as a review and analytical framework. The selected local communities are the Mentawai tribe, the slopes of Mount Merapi, and the Balinese in Indonesia. These three case studies show that the adaptations and strategies carried out by local communities are diverse and have different knowledge implications. The Mentawai tribe in maintaining the tradition of arat sabulungan and Balinese in revitalizing Wariga can adjust and adapt well when faced with natural ecological cycles and non-natural penetration. That is because its application is more flexible, practical, and intellectual than putting forward the device of beliefs and myths. While the case of the local community on the slopes of Merapi, which has local significance in the form of cosmological teachings in disaster management, tends to prioritize faith that is rooted more in myth than knowledge related to the objective world. Therefore, when this set of knowledge in local wisdom struggles to surpass marginalized status, the two cases of the Mentawai and Balinese communities can become persuasive and adaptive. In contrast, the local community on the slopes of Merapi is more challenging to adapt. The study also recommends that it is time for traditional knowledge originating from local wisdom in Indonesia to be adapted, modified and used as an essential resource in managing contemporary environmental issues effectively and collaboratively.
\end{abstract}

Keywords: Adaptation; Environment; Local wisdom; Religion.

Abstrak: Studi ini fokus pada bagaimana upaya adaptasi dan strategi bertahan komunitaskomunitas lokal di Indonesia terhadap tekanan non alamiah kepada alam dan nilai kearifan lokal mereka dalam menjaga dan melestarikan lingkungan. Literatur antropologis, ekologis, dan yang terkait tentang komunitas lokal dijadikan tinjauan dan kerangka analisis. Adapun komunitas lokal yang dipilih adalah suku Mentawai, masyarakat lereng Gunung Merapi, dan masyarakat Bali di Indonesia. Tiga studi kasus ini menunjukkan bahwa adaptasi dan strategi yang dilakukan oleh masyarakat lokal ini beragam dan memiliki implikasi pengetahuan berbeda. Suku Mentawai dalam mempertahankan tradisi arat sabulungan dan masyarakat Bali dalam merevitalisasi Wariga dapat menyesuaikan dan beradaptasi secara baik ketika berhadapan dengan siklus lingkungan alamiah dan penetrasi non alamiah. Hal tersebut karena penerapannya lebih fleksibel, praktis, dan bersifat intelektual daripada mengedepankan perangkat kepercayaan dan mitos. Sementara kasus masyarakat lokal di lereng Merapi yang memiliki kerifan lokal dalam bentuk ajaran kosmologi dalam penanganan bencana, cenderung mengedepankan keimanan yang lebih berakar pada mitos daripada pengetahuan yang berhubungan dengan dunia objektif. Karena itu, ketika perangkat pengetahuan kearifan lokal ini berjuang untuk melampaui status yang terpinggirkan, dua kasus komunitas Mentawai dan Bali bisa menjadi persuasif dan adaptif, sementara komunitas lokal lereng Merapi lebih sukar untuk beradaptasi. Studi ini juga merekomendasikan bahwa sudah saatnya pengetahun tradisional yang berasal kearifan lokal di Indonesia ini diadaptasi, dimodifikasi dan dijadikan sumber daya penting dalam mengelola isu lingkungan kontemporer secara efektif dan kolaboratif. 
Kata Kunci: Adaptasi; agama; kearifan lokal; lingkungan.

\section{Introduction}

In the early of 1972, the war against environmental damage was raised at the United Nations (UN) Conference on the Human Environment in Stockholm, Sweden, and later at the World Summit on Sustainable Development in Johannesburg, South Africa (2002), and at the UN Climate Change Conference in Bali (2007)(UNDP, 2007). The pollution and environmental damages that occurred in the sea, forests, and air were the result of the irresponsible, careless, or selfish human behaviors (Sonny Keraf, 2010). This is evidenced by destructive and exploitative behaviors in various regions in Indonesia, such as the widespread practices of illegal logging, illegal fishing, illegal mining, pollution, environmental crime, and environmental and forest degradation(Uy \& Shaw, 2010). These activities are usually driven by commercial profit which often makes them difficult to be controlled.

Any scholar such as Chiotinis (2006), Chang (2011a) and Dove (2006) agreed that these global changes are anthropogenic, and that local communities around the world are often the most profoundly affected, because in principle humans depend on their environment in their daily lives. Conversely, human activities influence and affect the environment. Whenever change happens in the environment beyond the limits of human adaptability, sustainability will be threatened. Such changes are increasingly common and are globally recognized as constituting a world-wide environmental crisis(Shaw, Pulhin, \& Pereira, 2010).

Local communities have a set of knowledge that they have traditionally inherited in protecting the nature and the environment. Many authors such as Rappaport (Rappaport, 1967), Rappaport (Rappaport, 1979) and Sponsel (Sponsel, 2011) have demonstrated that local wisdom of indigenous groups originating from ancient scientific knowledge and experience was ritualized to become religious faith and permeated by myth and legend. Their local wisdom for the natural environment is, in fact, a "cognized model" (or a 'cognicized model'), as opposed to the "operational model" of modern science.

However, in its development, the values of religion and local wisdom have experienced both pressure and marginalization naturally, as well as government pressure and other non-traditional forces, as the researches done by Nguyen (Nguyen, 2019), Arhem(Arhem, 2014), Rappaport (Rappaport, 1967), Lansing (Lansing, 2006) and Condominas (Condominas, 1994) on several local communities in Asia. These researchers generally argue that adaptation always occurs naturally, because the religious values and local wisdom of the local community itself is an expression of the long-term adaptation process to the natural environment. Rappaport argues that nature's adaptive effectiveness in human life is thought to be the primary criterion for cognized models (Rappaport, 1979). He calls these tribes as "ritually regulated population" and their environment as "ritually regulated ecosystem" (Rappaport, 1979). Therefore, they are not necessarily opposed to modern science if indigenous groups do not insist on dogmatic faith. However, Nguyen highlights more sharply from the non-natural aspects of how these local wisdom values have been able to adapt from government pressure and other non-traditional penetration (Nguyen, 2019).

In the case of local communities in Indonesia, religious values and local wisdom such as the cosmology of the indigenous community on the slopes of Mount Merapi, the Arat Sabulungan teachings of the Mentawai tribe, and Wariga or the seasonal calendar in Bali, are being marginalized, especially from non-natural aspects such as government pressure and non-traditional pressure in Indonesia. Each of these local communities has a different and varied adaptation strategy in the process of survival in response to the tension of indigenous people and the development of modernization in general. The various strategies show the uniqueness of the diversity of religious values and local wisdom that Indonesia has with thousands of local communities from thousands of islands in the Indonesian archipelago.

The study included a review of literature about the Mentawai tribe, the Mount Merapi tribe, and the Balinese tribe. Most of the government reports, and local statistics produced by government 
agencies and private research enterprises, were gathered in Indonesia. As a method of data collection, the literature review involved identifying, recording, understanding, meaning-making, and transmitting information. Data analysis involved comparing, contrasting, synthesis and critique.

This paper presents some of the challenges faced by three local Indonesian communities; the Mentawai tribe, the Mount Merapi tribe, and the Balinese tribe, in response to non-natural pressure such as marginalization from the government and other non-traditional pressures on the value of their local wisdom of preserving nature. These communities are used as case studies to demonstrate how religion and traditional approaches to ecological management as a traditional knowledge device that can adapt to pressure and change so that it remains a traditional value and knowledge in preserving nature and the environment.

\section{Theoritical Frameworks}

\section{Religion and Cultural Ecology}

The integration of religion and culture involves what Peter L. Berger called the "dialectical process". He considered that the fundamental dialectical process consisted of three steps: externalization, objectification, and internalization (Berger, 1996). Religion thus comes from the process of objectification which involves the relationship between the subject (human), culture and artifacts. Religion will happen when subjects externalize themselves through the creation of objects which are intended to create a differentiation, and then internalize the values of the creation through the process of cognition (Malefijt, 1995). This process will occur when a religion enters communities outside its constituent communities. It will then undergo a process of adjustment. There will be a compromise between retaining the religious values or symbols from the original culture and adapting to those of the new one. This produces a new form that is different from the religion and original culture (Wall, 1968).

Any discussion about nature, the environment and ecology must be in the context of the culture and society (Chiotinis, 2006). Humans have to interact with the environment or natural surroundings as part of life (Atan, Ruhaya, Md. Mahmudul Alam, Said, Jamaliah, Zamri, Mohamed, 2004). Anthropologists have found a harmonious relationship between culture and the environment in traditional societies because they have a very high dependence on living with nature. Generally, traditional communities have a cosmological view inherited from their ancestors (Bowie, 2001). A culture's cosmological view was reflected in its mythological repertoire in mythology, there is a pattern that unites contradictory realities and statements in harmony. Some scholars used the term coincidentia oppositorum for this pattern (Eliade, 1959). A myth will reveal the divine structure that can overcome and reconcile contention in greater depth than can be expressed by rational experience. Myths not only describe the origins of the world, animals, plants, and humans but also explain patterns of human interaction with the environment. Through the appreciation of a myth poured through ritual, one can imitate how to achieve the divine to participate symbolically in circumstances when humans were created and styled by the divine and supernatural.

Traditional societies have a certain attitude towards life, the world, man, and what they thinks is holy or sacred, so that their beliefs, outlook on life, social and cultural systems, and even the ceremonies, cannot be separated from the elements of the environment. In Mircea Eliade considered that the world for traditional societies was limited to an area that was already known, as nature, a region that had been "concentrated". Outside the region was a chaotic world (chaos), the abode of the spirits, jinni's, demons, and the like. The world could regularly return if there was a recreation of the cosmogony by the gods or supernatural powers through a ceremony. Principally in the view of anthropologists, the understanding of nature found in local traditions in the world generally means that the universe was composed of three layers: the upper world, a world of the divine (heaven), the place of the gods and the ancestors; the center world inhabited by living beings, namely humans, animals, and plants; and the underworld where living things when after they died. These three layers were connected by an axis, the axis mundi which was located in the center of the world that 
connected one layer to another. Through the axis mundi, humans could relate to the world above and the world below (Eliade, 1959).

There are several theories about the interactions between humans and the environment: environmental determinism; environment possibilism; cultural ecology; the ecosystem-based models of human ecology; the actor-based models of human ecology; and the systems models of human ecology (Iskandar, 2009, p. 6). In this discussion focusing on local wisdom, a theory of cultural ecology can be used to look at the interaction of cultures and environments. The principle of the theory is that culture has develops in the local environment. This approach offers a new understanding of how traditional societies effectively adapt themselves to their environment. Its success has been achieved mainly in small-scale studies of traditional communities (Iskandar, 2009).

\section{Local Wisdom and Environmental Issues}

The post-colonial era was a new historical era. It was also the beginning of including the local wisdom perspective in the systems of knowledge and local technology in sustainable development throughout the world, including in Indonesia (Dove, 2006). Local wisdom refers to a variety of cultural treasures that grow and thrive in a society that is known, trusted and recognized, and includes all kinds of important elements capable of reinforcing social cohesion among its citizens (Chiotinis, 2006).

Haba lists six important elements and functions of local wisdom first, it is a marker of the identity of a community; second, it has the cohesive aspect; third, it is not coercive or from above (topdown), but a cultural element that exists and lives in the community; fourth, it brings citizens together to create a community; fifth, it changes the mindset and feedback relationships of individuals and groups based on the culture; sixth, local wisdom promotes togetherness and appreciation, 'as well as being a mechanism to combine growth and belief, creating an integrated community (Haba, 2007, pp. 334-335). The sixth function confirms the importance of a local, knowledge-based approach to local knowledge to address humanitarian and environmental issues and conflict.

Other terms in the literature are similar to local wisdom, namely traditional wisdom (Agatha, 2016), indigenous wisdom (Verbos \& Humphries, 2015), indigenous knowledge (Chang, 2011b). Indigenous knowledge refers to the knowledge of indigenous people who live in certain geographic locations, and who have different systems of culture and belief from the modern, intellectual, world knowledge system. It has been created by a group of people through the generations living together in harmony with nature, and has grown in the local culture, adjusting to the circumstances and needs of the community (Capra, 1982, p. 21). 'This knowledge is the result of creativity and innovation, or of ongoing trials to adapt to new local conditions created by internal and external influences (Joshi \& Sunaryo, 2003, p. 12).

Local knowledge is a broader concept that refers to the knowledge held by a group of people who live in certain areas for long periods of time. Thus, the word "indigenous" in indigenous knowledge refers to the nature of the place where knowledge is grown locally, and not to whether or not the original actor developed the knowledge. If we are guided by the concept of the past, indigenous knowledge together with local knowledge and the subsequent exposure of both terms mean the same. Local knowledge of a community of farmers who live in a specific area is usually obtained by long experienced that is passed down from generation to generation (Binsbergen, 2009).

\section{Result and Discussion}

This section will globally describe some local wisdom in traditional society in Indonesia related to environmental issues. Those include the local knowledge of Mentawai tribe about the conservation of natural resources and forest, the local wisdom of the people who live on the slopes of Mount Merapi about managing its eruptions, and the local wisdom of Bali about managing climate change through the traditional calendar, Wariga. 


\section{The Natural Resources and Forest Conservation in the Mentawai tribe: Local Wisdom}

Mentawai is an archipelago consisting of dozens of islands. The three biggest islands are Siberut, Pagai, and Sipora. The biggest island is Siberut with an area of 4,480 km2 (Asian Development Bank, 2001 , p. 20). Since the era of regional autonomy, Mentawai Islands are no longer included in the district of Padang Pariaman, but are a separate district called the Mentawai Islands within the province of West Sumatra. The capital city is Pagai (Schefold, 2002).

The distance between Padang and the Mentawai Islands is about $135 \mathrm{~km}$ across the Indian Ocean which has high waves and is often dangerous. Therefore, the transportation to the islands really depends on the weather; if it is the hurricane season, the ships rarely pass through the islands. This situation has been going on for hundreds of years, and this has made the islands become "isolated." However, this has actually been very beneficial for the flora and fauna that exist only on these islands (G. A. Persoon, Schefold, De Roos, \& Marschall, 2002).

Indirectly, this condition also makes the people living in these islands and their culture has its own characteristics, following the natural state. Mentawai forests, in addition to supporting the lives of the people, are also an ecosystem for a number of species endemic to the islands, such as the joja or Mentawai monkey (Presbytis potenziani), the bokkoi (Macaca pagensis), the simakobu (Simias concolor), and the bilou or dwarf gibbon (Hylobates klosii). It is natural that the Mentawai region becomes one of the protected areas in Indonesia as the "reserved biosphere." The Siberut National Park area was designated by Ministerial Decree No.407/Kpt-II/93 retroactively from 1992 (Eindhoven, 2009).

In fact, the people of the Mentawai tribe have the wisdom in keeping forest conservation, which is through sabulungan wisdom that has been deeply ingrained in their society. This teaches that the forest is not for life today, but it is for future generations. Through sabulungan wisdom, they can determine the right place for farming, for example, after cutting the trees, they replace them with the new ones so that it will not cause the landslides.

Sabulungan comes from the words sa and bulung. Sa means a bundle, bulung means leaf. Sabulungan teaches a balance between nature and human (Tulius, 2012). This belief teaches people to treat nature, plants, water, and animals like themselves. For the Mentawai tribe, leaves are considered to have magical powers to heal and revive, and they are always included in Mentawai tribal ceremonies (Schefold, 1973). The Mentawai community are well known for their amazing ability to heal the sickness by using foliage that grows wildly in the forest.

The leaves are also believed to be able to connect the Mentawai people with the ruler of the universe called Ulau Manua. According to their belief, leaves or, more broadly trees and forests, are the dwelling for the gods and must be respected. Otherwise, disaster will occur. There are three deities revered in sabulungan teachings. The first is Tai Kaleleu, the god of forests and mountains. Traditional parties conducted before hunting are dedicated to this god. The second is Tai Leubagat Koat, the sea god or god of water. Water is revered for giving life, but sometimes also causes a storm. Tai Leubagat Koat is like Lord Shiva in the Hindu religion. Third is Tai Kamanua, the god of the sky and rain, and the life-giver. This god maintains the balance of nature (Schefold, 1992).

Sabulungan belief is similar to the Kaharingan teaching in the Dayak community in Kalimantan. The people greatly respect nature because they believe all living things have an owner and the owner would be upset if their property is tampered with. Sabulungan also maintains close ties between the people of the Mentawai tribe that consists of four parts with 76 subtribes. In addition to the underlying life and beliefs, sabulungan also animates the lives of tribal art in Mentawai.

However, the value of local wisdom and the local Mentawai community's religion in protecting the forest and nature has had to deal with forest concessions (HPH) and timber utilization permits (IPK) by some companies that began to proliferate on the island of Siberut. By 1970, the government had split the Siberut forest area of 408,000 hectares into four concessional leaving only 60,000 to 65,000 hectares for wildlife reserves and for settlements and agriculture (Kompas, 2006). Originally, the Mentawai people had chosen hardwood to make their Uma (communal home). However, after the hardwoods were logged, they had only softwood and it was feared that this would be quickly 
depleted. That, of course, would threaten the ecological, social and cultural life of the Mentawai tribe(G. Persoon, 1989).

Because of the exploitation of the natural resources of Mentawai, the "rulers" also expected them to contribute to the regional. According to Myrna Eindhoven, when Mentawai was still part of the Padang Pariaman district, it donated almost three-quarters of the total district revenue, the main source coming from the export of copra, rattan and timber (Eindhoven, 2007). Most profits were never returned and enjoyed by the Mentawai people themselves; the nomads (employers and authorities) enjoyed the surplus generated from the forests, while natural resources and Mentawai forests continued to be exploited.

In addition to the influx of outside influences, both during the colonial period and after the independence of Indonesia, the Mentawai tribal culture and religion have been used as the commodification of both economy and politics and also the contestation of the rulers and businessmen. Their religion and culture have also become the target of missionaries and proselytizers (da'wah) of major religions (Protestantism and Islam). As stated by Gerald A. Persoon, the great religions have invaded the local beliefs, especially sabulungan and other rituals. Sabulungan was considered a heretical belief, and all the ceremonial objects were burnt and destroyed (G. Persoon, 2006).

Based on the pressures on the local values of Arat Sabulungan, critical voices began to emerge as damages and the loss of some biodiversity and cultural heritage were caused by irresponsible parties. These voices came from several international organizations who, since the late 1970s, had been actively working for Mentawai, for example, Survival International, World Wide Fund for Nature (WWF), UNESCO, the Asian Development Bank and Conservation International (CI) (Eindhoven, 2009). Their view contrasted with the vision of the government and several other international agencies who viewed the Mentawai tribe as a backward, marginal group, responsible for the destruction of their natural habitat (G. Persoon, 1989). Among the development program is to stimulate awareness of the Mentawai people of the patterns of life changes and introduce the concept of renewal that is easily integrated to improve their lives.

Meanwhile, for the Mentawai people, there is an attempt to show their identity as indigenous people who live in the endangered tropical forests, especially after being apart from Padang Pariaman and forming their own district. According to Glossanto, there are at least some adaptation efforts and community strategies in maintaining this arat sabulungan tradition. First, the stage of resistance of the sikebukat (traditional leaders) fight against the Sabulungan prohibition movement by avoiding and fleeing to the villages upstream of the river that is difficult to reach by the police. Also, the sikebukat who in their youth experienced the treatment of the police who tried to destroy their cultural attributes try to hide or make artificial objects to trick the police. Second, revitalizing the local values of arat sabulungan is through the local content of the Budaya Mentawai (Bumen/Mentawai Culture) at schools starting at the elementary and secondary levels. This local curriculum is compiled by the local government in collaboration with the NGO Citra Mandiri Foundation (YCM). They realize that this arat sabulungan, as a way of life for the Mentawai people, will not be able to be applied as previously, but will continue to be pursued and preserved for their future generations (Glossanto, 2019, p. 92).

And third, the inculturation of the teachings of the Catholic religion is through the equalization of the concept of Ulaumanua which is seen as the highest spirit in the teaching of arat sabulungan with the concept of God in celestial religion, especially Catholicism. This effort offers an opposite approach to the government and the great celestial religion in the Sabulungan prohibition in Mentawai, especially in Siberut. The early missionaries tried to get to know and learn the local culture and to give credit to it. Seeing the attitude of the missionaries who did not burn the tools of Sikerei and did not forbid holding traditional ceremonies, many Mentawai people in Siberut were willing to become Catholics (Glossanto, 2019). 


\section{Disaster Management on The Slopes of Mount Merapi: Local Wisdom}

Mount Merapi is located on the borders of four regencies in two provinces: the south slope in Sleman Regency (Yogyakarta), the west slope in Magelang Regency, the north and east slope in Boyolali Regency, and the southeast slope in Klaten Regency. The last three regencies are located in the province of Central Java. It is a volcano that has an altitude of 2,942 meters. It is one of the most active volcanoes in the world, and one of about 600 active volcanoes in Indonesia (Statistics Centre Bureau, 2008). From 1968, it was recorded that an average of 7.5 years occurred so devastating catastrophic eruptions of hot clouds of ash that changed the environmental conditions around the slopes of Mount Merapi. The findings recorded for 1994, 2001 and 2006 showed that Mount Merapi put out lava and hot clouds that spelled disaster for the surrounding area (National Development Planning Agency, 2006).

Although they live in disaster-prone areas, the traditional society does not regard this mountain as a threat. Merapi has an economic, ecological and even spiritual function for the surrounding community. The area is the last bastion of biodiversity and the backbone of the geohydrology system for the region, as a provider of the tower water needs of the people of Yogyakarta, Magelang, Boyolali, and Klaten. In addition, Merapi has the function as flood and erosion control, with the existence of tropical rainforests around its slopes, and as a water catchment area that Merapi designated as protected comrades subordinate.

The local people of the slopes of Mount Merapi have local wisdom values, especially the teachings of cosmology. Through this teaching, they believe that Merapi's supernatural myths are not only tangible symbols and a way of life for the local communities but also a source of transcendental beliefs that build a strong dynamic interaction and form a cultural ethos. This statement can be found in some researches done by some scholars such as; Baedhowi (2008), Hatley (2007), Ghazali (2008) Kusumasari (2012) and Laksono (1985). Baedhowi has expressed the Kejawen cosmology view that, if a community upholds the principle of rahayuning rat (natural safety), it is very useful in mamayu hayuning Bawan (changing attitudes rahmatan lil alamin). For the Javanese, this cosmology unity is a whole-life attitude to look at and respond to the jagad cilik (microcosm) and the jagad gedhe (macrocosm). Both determine and create karahayon (welfare) (Baedhowi, 2008).

Furthermore, Ghazali stated that traditional communities put Mount Merapi in a macrocosm position under the control of Kanjeng Ratu Sekar and Kedaton Kyai Sapu Jagad, Kayangan Dlepih under Sang Hyang Pramoni, and Mount Lawu under the control of Kanjeng Sunan Lawu, as well as the South Sea under the control of Kanjeng Ratu Selatan. These four macrocosms and microcosm of Merapi society under the control of the Mataram kingdom (Ghazali, 2008).

Related to the Mount Merapi disaster, the cosmological teachings they believe advocate conducting a number of ceremonies and rituals that are accompanied by sacred utterances (do'a) dan sacrificial offerings (sesajen). This ritual aims to ask for safety from the threat of disaster so that their good relationship with nature is awake and harmonious, and the eruption of Merapi is not catastrophic (Laksono, 1985). This ceremony is usually called a baretan, a kind of village event or ceremonial "selametan" which is traditionally held in the month of Sura on Kliwon Friday night in the Javanese calendar.

In addition, the cosmological teachings of the community on the slopes of Mount Merapi also teach how to read natural signs and traditional observations toward Mount Merapi activities such as hunches, whips, thunder, lightning and other living creatures' behaviors (Laksono, 1985). This local wisdom can predict when they will survive and when they will flee from a disaster. Moreover, the community on the slopes of Mount Merapi has a strong community structure through local values such as mutual cooperation, solidarity and a strong network in dealing with disasters (Kusumasari \& Alam, 2012). They also have spiritual leaders like pepundhen, a spiritual figure and cosmologist like Father Yoso as a abdi dalem (servant) in the Surakarta Palace (Kraton Surakarta) (Baedhowi, 2008). This position was also held by Mbah Marijan, the 85-year-old man who was ordered by the Sultan Hamengkubuwono IX to become the caretaker of Merapi. From some Mount Merapi eruptions from 1994 to 2006, a polemic and a discussion of the pros and cons of the disaster management occurred 
between the government and the people of Mount Merapi. This is considered as a form of government pressure toward the community local wisdom in disaster management. The peak of the polemic occurred when the community evacuation process was affected by the eruption of Mount Merapi in 2006 through a decision of BPPTK (Badan Penyelidikan dan Pengembangan Teknik Kegunungapian/the Investigation and Development Agency Mountain Engineering) that set the alert status to four in 2006, the highest status. Furthermore, through that agency, the Yogyakarta and Central Java provincial government had tried to prepare the administration of emergency evacuation and the evacuation of people who lived on the slopes of Mount Merapi to the refugee camps that had been set up (National Development Planning Ageny, 2008).

The views of the government on disaster management were seriously challenged by a society which still followed the traditional view of the Merapi society's role model, Mbah Marijan. He had his own view on the emergency response to eruption of Mount Merapi. He said that the government should not issue the instructions to evacuate feverishly since the instructions were not popular among the community. The people really believed that the gatekeeper Mbah Marijan was a messenger from the ruler of Merapi, so it was not surprising that his word was believed by the people, rather than the instructions of the government (Ghazali, 2008). Because of it, the polemics became worse and worse. Even there was the resistance from the society towards the government. Therefore, it is considered that disaster management carried out by the government so far still uses conventional methods, topdown, and tends to be sectoral and external by placing local communities as victims and passive, even though they have the local wisdom values with a set of teachings in anticipating and preventing disasters.

Based on the dilemma and the penetration of local wisdom values in managing the disaster of Mount Merapi eruption above, a number of community groups have adapted and applied local values in an agreed open and informal organization called the Paguyuban Sabuk Gunung Merapi (PASAG Merapi). The organization that was established in 1994 under the initiation of the Indonesian Kappala Society and supported by OXFAM Great Britain Indonesia and other donors has experienced ups and downs and various obstacles (Ghazali, 2008).

This local non-governmental organization, however, continues to carry out its mission through activities and vigorously voices the importance of community-based anticipatory efforts and their local wisdom. Through the missions to unite the people of the Merapi community members, preserve the environment and environmental wisdom, and increase community disaster alertness, they have carried out some various activities such as conducting the disaster management workshops, building community empowerment, and forming the communication media such as community radio and other media. In addition to the informal organization PASAG Merapi, there are many more Merapi slopes community activities both in small communities and initiated by other institutions that have awareness of the importance of local community involvement and local wisdom in managing disasters and preserving their environment and culture.

\section{The Issue of Climate Change and Global Warming through the Indigenous Traditional Calendar (Wariga), Bali}

The concerns about the impact of climate change have also involved Bali island. Since the reform and decentralization of Indonesian politics, there have been many calls to save the environment and culture. According to researchers such as; Picard (1996), Nordholt (2007), Vickers (1996), Thompson (1998) and Adidjontro (1995), with its culture-based tourism, Bali has even been warned by various external influences to rescue its own local culture. The development activities that are not well controlled as the tourism sector is expanding very rapidly causing massive environmental damage (Dłuzewska, 2008).

The culture and religion of Bali, in the opinion of Clifford Greetz (1973), cannot be separated from each other. One hundred years ago, there was local knowledge of how to create harmony between human and nature by keeping the earth and the environment from damage, for example with irrigation patterns, planting, environmental ethics and regulatory seasons. One of them is the traditional structures that have a calendar reading of the seasons and the movement of celestial 
objects that were formulated hundreds of years ago. This Balinese traditional calendar, known as Wariga, is a calendar system that combines the lunar and solar systems. It not only determines or "reads' the season but also functions as an agricultural calendar which regulates the season, cropping patterns and environmental settings. The calendar also sets the ritual ceremonies, such as gebug ende (festival of rain).

Balinese Hinduism teaches education namely the three frameworks Tattwa, Susila, and Upacara. Hindu religious ceremonies include knowledge about holy days or pedewasan, saints, holy buildings. Knowledge of holy days can be gained through Wariga. In fact, Wariga is used not only to learn about the holy days (good) for ceremonial purposes but also to learn about pesasihan, pawukon, wawaran, dadawuhan, date and panglong, pakarman and everything that is caused by nature or the effects of the stars (Dwija, 2016).

Wariga means: Wari $=$ wara $=$ main, wari $=$ wara $=$ warah $=$ instructions $=$ guide, ga $=$ motion $=$ path = deed. According to the Balinese dictionary, Wariga is about calculating the good and bad days, while according to the dictionary Javanese- Indonesian work of L. Mardiwarsito, Wariga is an interpreter or astrologer, tasked with finding the day/time that is good for a variety of purposes in the village. Another opinion is that Wariga is a science of the good and bad times for a work activity or yadnya, in order to gain blessing or all the ceremonies that are performed (Dwija, 2016). Local knowledge is widely scattered across the nation, in the form of a traditional calendar that is phenological behavior that is associated with changes in plants, animals, and other natural phenomena. Examples of some of the traditional calendars include Kala Sunda (West Java), Pranata Mangsa (Central Java), Tike Lime (Lombok), Dayak Ngaju (Central Kalimantan), Lamaholot (Flores), Tetemasa (Madura), Katiko (Minangkabau), Keunong (Aceh), and Pananrang (Makassar) (Hiwasaki, Luna, Syamsidik, \& Marcal, 2015).

However, the problems faced by the people of Bali are the changing or extension of the seasons because of the impact of climate change. This change has resulted in a shift in the Earth's rotation around the sun so that there was a full moon twice in one month in October 1993, May 1999 and May 2004. In the tradition of Bali known as nampih sasih (renewal month) (Sudarsana, 2017). The change in season is exacerbated by geographical features, predominantly the hilly region of Bali Aga and the coral-restricted steep south coast of Java, so that these areas experience more anomalies of weather than other regions of Bali. Because of this geographical difference, these regions experienced a shorter rainy season in the early years. Meanwhile, in October-December they were experiencing drought. In these months the people often held ceremonies for rain (gebug ende). Thus the shifting seasons and changed environmental conditions will affect the organization of religious rituals. The impact of the shift of the season looked from the damage to the social order of Balinese life, such as crop failures, the drain on water sources and other social impacts (Sudana, Mahardika, \& Dharmaadi, 2019).

Even now, there have been many critical voices against the commercialization of culture as a "lawful" right for tourism. In Bali, culture was no longer intended to harmonize human life and nature. The Balinese became separated from nature and have exploited and manipulated it. Kurnianingsih (2008, p. 12) noted that much land that is supposed to function as nature conservation area, such as mangroves, green lanes and farmland, has been transformed into hotels, highways, residential buildings and other commercial structures. Thus, according to him, the island dubbed by Greetz (Geertz, 1973) as the "Theatre State", is currently experiencing serious environmental problems caused by the density of tourism, such as beaches, seas and lakes that are polluted, inorganic waste that has increased sharply, energy lack of clean drinking water, and air pollution.

A problem that requires a solution is how Bali's local culture and religion can adapt to the problems of the earth and the environment. Therefore, Bali's Hindu Association held a meeting to revise the calendar change to the fall season due to the full moon (Ginaya, 2018). In this way, Balinese culture transformed and adapted to environmental issues caused by the irresponsible treatment of nature. 


\section{Adaptation as a Response to 'Being Marginalized'of Local Wisdom in the Modernization Process}

Local wisdom or indigenous knowledge grows through oral tradition or through methods such as informal education. However, it can also be lost or reduced. Knowledge that is not relevant to changing circumstances and needs will also be lost or abandoned.

In an effort to preserve the sustainability of natural resources, various groups began to use local knowledge as well as an alternative to the system of knowledge and modern technologies that lead to the destruction of the environment (Assiamah E, Y, Muller, K, Domfeh, 2018). Some studies have revealed that local wisdom about drug use, traditional medicine, farming, and traditional architecture has consistency with the logic of modern science (Chang, 2011a).

Sometimes a technology developed elsewhere is tried and adapted to local environmental conditions so that it becomes an integral part of the existing technology, culture and social system. Therefore, an external technology will become part of local technology as befits the technologies they are developing by themselves. The farmers' practical knowledge about local ecosystems, for example, the natural resources and how they interact will be reflected both in farming techniques and skills to manage their natural resources.

The process of adapting local wisdom values can be in very varied forms and formats. One of them is revitalization and modification with combining elements of modern knowledge and scientific proof, and is presented in a new format. As a result, the wisdom can remain fit for the present, and possibly the future, especially in the context of adaptation to the global climate change.

According to Sobirin, real actions that attempt to revitalize traditional knowledge are: first, scientific studies should be carried out to identify all the traditional wisdom that "is" or "has ever existed" in the archipelago with regard to adaptation to the impacts of climate change. Second, some locations of the origin of traditional knowledge should be selected as pilots and climatological stations built to correlate local knowledge with scientific knowledge. Third, the increases in the capacity of field instructor of the traditional knowledge and its relation to the impacts of climate change are needed. Fourth, the rights of recovery and institutional improvement of traditional wisdom. Fifth, the legal aspects need to be supported as the realization of the government's political will on the dissemination and extension of traditional wisdom cope with the impacts of climate change (Sobirin, 2011).

From the ecological point of view of culture, adaptation can be interpreted as a strategy to handle and respond to changes in the ecosystem and social system. More broadly, human adaptation strategies can be defined as behaviors such as allocating resources in response to these problems, making choices, and taking appropriate action in accordance with the social, cultural, economic and ecological environment/ system in which they live (Iskandar \& Ellen, 2004, p. 21).

\section{Conclusion}

What appears from the discussion of the three cases in this article shows the variety of adaptation efforts undertaken by local communities in maintaining local wisdom and the environment from the onslaught of modernization and marginalization by both governmental pressure and non-traditional environmental damage. In this context, the adaptation and strategy carried out by the Mentawai local people in maintaining the arat sabulungan tradition and the Balinese people in revitalizing Wariga when faced with predictable regular natural environmental cycle are more intellectual than faith. While the case of local community on the slopes of Merapi, which has local wisdom in the form of cosmological teachings and various derivative rites, tends to have faith that is more rooted in imaginary capacities than knowledge related to the objective world. Therefore, when local wisdom struggles to surpass marginalized status, the two cases of the Mentawai and Balinese can be persuasive. At the same time, the belief of the community on the slope of Merapi is more challenging to adapt.

Thus, the knowledge of indigenous or local wisdom as a collective experience accumulated from generation to generation needs to be developed as part of the enrichment and completes the assembly 
of technological innovation sustainable future, including for conservation of forests and natural resources, disaster management and climate change mitigation efforts.

The excavation of local wisdom in matters of global environmental issues is already being carried out by some researchers from different institutions and organizations, both inside and outside Indonesia. Some local cultural wisdom about anticipating and addressing global environmental issues has the potential to be developed for other communities and areas after revitalization and adaptation to fit the local cultural and environmental conditions.

\section{References}

Adidjontro, G. J. (1995). Bali, Jakarta's Colony: Social and Ecological Impact's of Jakarta-based Conglomerate in Bali Touristic Industry. Perth: ARC Murdoch University Press.

Agatha, A. (2016). Traditional Wisdom in Land Use and Resource Management Among the Lugbara of Uganda. SAGE Open, 6(3), 215824401666456. https://doi.org/10.1177/2158244016664562

Arhem, N. (2014). Forests, Spirits, and High Modernist Development. Sweden: Acta Universitatis Upsaliensis.

Asian Development Bank. (2001). Project Compilation Report on the Biodiversity Conservation Project in Flores and Siberut (Loan 1187-INO[SF]) in Indonesia.

Assiamah E, Y, Muller, K, Domfeh, K. A. (2018). Transdisciplinary approach to natural resource governance research: a conceptual paper. Management of Environmental Quality: An International Journal Article Information :, 29(1), 15-33. https://doi.org/10.1108 MEQ 0420160034

Atan, Ruhaya , Md. Mahmudul Alam, Said, Jamaliah , Zamri, Mohamed. (2004). The impacts of environmental, social, and governance factors on firm performance: Panel study of Malaysian companies. Management of Environmental Quality: An International Journal, 15(6), 622-628. https://doi.org/10.1108/1477783041056070

Baedhowi. (2008). Kearifan Lokal Kosmologi Kejawan: Studi Post Colonial Pandangan Kosmologi Romo Yoso dan Implikasinya bagi Warga Tutup Ngisor-Magelang. In Agama dan Kearifan Lokal dalam Tantangan Zaman. Yogyakarta: Pustaka Pelajar.

Berger, P. L. (1996). Sacred canopy: Elements of a sociological theory of religione. UK: Open Road Media.

Binsbergen, W. M. J. (2009). Expressions of traditional wisdom: What Africa can teach the world today. Bulletin Des Séances de l'Académie Royale Des Sciences d'Outre-Mer, 55, 281-305.

Bowie, F. (2001). The antroplogy of Religion: an Introduction. UK: Blackwell Publishers.

Capra, F. (1982). The turning point: Science, society, and the rising culture. Toronto, Ontario, Canada: Bantam Books.

Chang, W. C. (2011a). Rethinking resource identification and utilization: The reconstruction of indigenous ethnoecological knowledge in Fata'an Wetland, Taiwan. Management of Environmental Quality: An International Journal, 22(2), 187-199. https://doi.org/10.1108/14777831111113374

Chang, W. C. (2011b). Rethinking resource identification and utilization The reconstruction of indigenous. Management of Environmental Quality: An International Journal, 22(2), 187-199. https://doi.org/10.1108/14777831111113374

Chiotinis, N. (2006). The request of sustainability and architecture as cultural paradigm. Management of Environmental Quality: An International Journal, 17(5), 593-598. https://doi.org/https:// doi.org/10.1108/14777830610684558

Condominas, G. (1994). We have eaten the forest: the story of a Montagnard village in the Central Highlands of Vietnam. New York: Kodansha Globe.

Dłuzewska, A. (2008). Direct and indirect impact of the tourism industry on drylands: The example of Southern Tunisia. Management of Environmental Quality: An International Journal, 19(6), 661-669. https://doi.org/10.1108/14777830810904894

Dove, M. R. (2006). Indigenous People and Environmental Politics. Annual Review of Anthropology, 35(1), 191-208. https://doi.org/10.1146/annurev.anthro.35.081705.123235

Dwija, B. (2016). Peranan Wariga Bali Pada Tanaman Untuk Upacara Adat dan Agama.

Eindhoven, M. (2007). Penjajah Baru? Identitas, Rerpresentasi dan Pemerintahan di Kepulauan Mentawai Pasca Orde Baru. In Politik Lokal di Indonesia (p. 91). Jakarta: Yayasan Obor Indonesia.

Eindhoven, M. (2009). The influence of history and politics on the environmental future of the Mentawai Archipelago. Asia-Pacific Forum 44, 55-81.

Eliade, M. (1959). The Secred and the Profan, The Nature of Religion. New York: Harcourt, Brace \& World Inc.

Geertz, C. (1973). The Interpretation of Cultures. New York: Basic Books, Ins, Publisher.

Ghazali, M. I. (2008). Pasag Merapi: Kebijakan Lokal Manageman Disaster, Pola Penanganan Darurat Letusan Merapi 2006. In Agama dan Kearifan Lokal dalam Tantangan Zaman (p. 213).

Ginaya, G. (2018). The Balinese calendar system: From its epistemological perspective to axiological practices. 
International Journal of Linguistics, Literature and Culture, 4(3), 24-37.

Glossanto, K. (2019). Sabulungan Dalam Tegangan Identitas Budaya: Kajian atas Religi Orang Mentawai di Siberut Selatan. Universitas Sanata Dharma Yogyakarta.

Haba, J. (2007). Revitalisasi Kearifan Lokal: Studi Resolusi Konflik di Kalimantan Barat, Maluku dan Poso. Jakarta: ICIP dan Eropean Commision.

Hatley, B. (2007). Theatre and Local Cultural Revival after the 2006 Yogyakarta. Masyarakat Indonesia, Majalah Ilmu-Ilmu Sosial Indonesia, 32(2), 47-56.

Hiwasaki, L., Luna, E., Syamsidik, \& Marcal, J. A. (2015). Local and indigenous knowledge on climate-related hazards of coastal and small island communities in Southeast Asia. Climatic Change, 128(1-2), 35-56. https://doi.org/10.1007/s10584-014-1288-8

Iskandar, J. (2009). Ekologi Manusia dan Pembangunan berkelanjutan. Bandung: Program Studi Ilmu Lingkungan Universitas Padjajaran.

Iskandar, J., \& Ellen, R. . (2004). Development of Sustainable Cultural Tourism in an Indigenous Community: A Case Study of Western Java, Indonesia. Bandung: University of Padjadjaran Press.

Joshi, L., \& Sunaryo. (2003). Peranan Pengetahuan Ekologi Lokal dalam Sistem Agroforestri. Bogor: World Agroforestry Centre (ICRAF) Southeast Asia Regional Office, Indonesia.

Kurnianingsih, A. (2008). Simulacra Bali: Traditional Ambiguity of Bali People. Yogyakarta: Insist Press.

Kusumasari, B., \& Alam, Q. (2012). Local wisdom-based disaster recovery model in Indonesia. Disaster Prevention and Management: An International Journal, 21(3), 351-369. https://doi.org/10.1108/09653561211234525

Laksono, P. (1985). Persepsi Setempat dan Nasional Mengenai Bencana Alam, sebuah Desa di Gunung Merapi. In Peranan Kebudayaan Tradisional. Jakarta: Yayasan Obor Indonesia.

Lansing, S. J. (2006). Perfect Order: Recognizing Complexity in Bali. Princeton, NJ: Pinceton University Press.

Malefijt, W. H. (1995). Religion Studies. Mineapolis: Fortress Press.

National Development Planning Agency. (2006). Preliminary Damage and Loss Assessment: Yogyakarta and Central Java Natural Disaster. Jakarta: National Development Planning Agency.

National Development Planning Ageny. (2008). Report on Monitoring and Evaluation of the Rehabilitation and Reconstruction Processes After Earthquake in Yogyakarta and Central Java Provinces. Yogyakarta.

Nguyen, Q. D. (2019). Complementarity between humans and nature: Adaptive local knowledge in a protected area of northern Thailand. Environmental Development, 30(February), 89-102. https://doi.org/10.1016/j.envdev.2019.03.001

Persoon, G. (1989). Beyond Dreaming: Environmental planning for man and nature on Siberut (West Sumatra, Indonesia). In Mentawai: Identitaet und Wandel auf indonesischen Ausseninseln (pp. 199-224). Bremen: Veroeffentlichungen aud dem Uebersee-Museum Bremen, Reihen C, Deutsche Geo- graphische Blaetter, N.F., Band 5.

Persoon, G. (2006). Religion and Ethnic Identity of the Mentawaians on Siberut (West Sumatera). In Hinduism in Modern Indonesia (p. 114). London, and New York: Routledge and Curzon.

Persoon, G. A., Schefold, R., De Roos, E., \& Marschall, W. (2002). Bibliography On The Islands Off The West Coast Of Ssumatra (1984-2002). Indonesia and the Malay World. https://doi.org/10.1080/1363981022000064410

Pichard, M. (1996). Bali: Cultural Turism and Touristic Culture. Singapore: Archipelago Press.

Rappaport, R. A. (1967). Ritual Regulation of Environmental Relations among a New Guinea People. Ethnology, 6(1), 17-30. https://doi.org/10.2307/3772735

Rappaport, R. A. (1979). Ecology, meaning, and religion. Richmond: North Atlantic Books.

Schefold, R. (1973). Religious Conceptions on Siberut, Mentawai. Sumatra Research Bulletin (Berita Kajian Sumatera), 2(1), 12-24.

Schefold, R. (1992). Shamans on Siberut: mediators between the worlds. In Mentawai Shaman, Keeper of the Rain For est: Man, Nature, and Spirits in remote Indonesia (pp. 105-117). New York: NY.: Aperture.

Schefold, R. (2002). Mentawaians. In Encyclopedia of World Cultures Supplement (pp. 207-217). New York: Gale Group \& Thomson Learning.

Schulte Nordholt, H., \& van Klinken, G. (2007). Renegotiating Boundaries: Local Politics in Post-Suharto Indonesia. In KITLV Prrss. https://doi.org/10.1163/9789004260436_002

Shaw, R., Pulhin, J. M., \& Pereira, J. J. (2010). “Chapter 1 Climate change adaptation and disaster risk reduction: An Asian perspective" In Climate Change Adaptation and Disaster Risk Reduction: An Asian Perspective. In Community, Environment and Disaster Risk Management (Vol. 5, pp. 349-372). https://doi.org/10.1108/S2040-7262(2010)5

Sobirin. (2011). Kearifan Lokal dan Perubahan Iklim. Kompas.

Sonny Keraf. (2010). Environmental Ethics. Jakarta: Kompas Publisher.

Sponsel, L. E. (2011). Religion and Environment: Exploring Spiritual Ecology. Religion and Society, 1(1), 131-145. 
https://doi.org/10.3167/arrs.2010.010109

Statistics Centre Bureau. (2008). Bantul in Figures 2008. Yogyakarta: BPS Press.

Sudana, O., Mahardika, O., \& Dharmaadi, I. P. A. (2019). Mobile Note Application for Bendesa Adat at Bali. Scientific Journal of Informatics, 6(2), 160-169. https://doi.org/10.15294/sji.v6i2.19705

Sudarsana, I. K. (2017). Konsep Pelestarian Lingkungan Dalam Upacara Tumpek Wariga Sebagai Media Pendidikan Bagi Masyarakat Hindu Bali. Religious: Jurnal Studi Agama-Agama Dan Lintas Budaya, 2(1), 1-7.

Thompson, H. (1998). Cultural Sensitivity of Tourism Development in Bali. In Tourism Resources, Impact and planning (p. 21). Hamilton: University of Waikato.

Tulius, J. (2012). Family Stories: Oral Tradition, Memories of the Past, and Contemporary Conflicts over Land in Mentawai - Indonesia proefschrift. In Universiteit Leiden (Vol. 18). https://doi.org/10.1016/01974556(91)90120-y

UNDP. (2007). Human Development Report 2007/2008 Fighting Climate Change: Human Solidarity in a Divided World. NY, USA: UNDP.

Uy, N., \& Shaw, R. (2010). No Title. In Chapter 16 Climate change adaptation in ASEAN: Actions and challenges (pp. 349-368). https://doi.org/10.1108/S2040-7262(2010)0000004022

Verbos, A. K., \& Humphries, M. T. (2015). Indigenous wisdom and the prme: Inclusion or illusion? Journal of Management Development, 34(1), 90-100. https://doi.org/10.1108/JMD-01-2013-0016

Vicker, A. (1996). Bali: A. Paradise Created. California: Periplus Edition.

Wall, A. de. (1968). Religion and Culture. New York: Mac Millan.

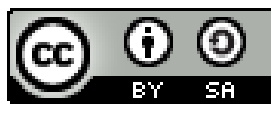

(C) 2020 by the authors. Submitted for possible open access publication under the terms and conditions of the Creative Commons Attribution (CC BY SA) license (https://creativecommons.org/licenses/by-sa/3.0/). 